\title{
Ferritin in Crohn's disease tissue: detection by electron microscopy
}

\author{
P. J. WHORWELL, R. C. BALDWIN, AND R. WRIGHT \\ From the South Laboratory and Pathology Block, Southampton General Hospital, Southampton
}

SUMMARY Using immune electron microscopy, an attempt has been made to visualise viral particles in Crohn's disease tissue and faeces. No particles resembling viruses were observed, but in the absence of a specific antiserum a negative result does not exclude the presence of a virus, particularly if it is sparsely distributed. Compared with controls, an abundance of a $12 \mathrm{~nm}$ particle was found in all Crohn's disease tissue and one small intestinal lymphoma. This particle has been identified as ferritin and is unlikely to be of aetiological significance.

The report in 1970 by Mitchell and Rees of a transmissible agent in Crohn's disease renewed interest in a possible viral aetiology for this condition. Since then, this work has been reproduced by some (Cave et al., 1973; Taub et al., 1974a, b; Cave et al., 1975 a, b) but others have consistently failed to repeat it (Bolton et al., 1973; Heatley et al., 1975).

In 1975, Aronson and his colleagues reported the isolation by tissue culture techniques of a viral agent from Crohn's disease tissue which has been tentatively classified as a small RNA virus. It has also been isolated from patients with other intestinal disorders, but in only two of 16 controls (Beeken et al., 1976). Additional evidence for a transmissible agent in inflammatory bowel disease stems from the demonstration of lymphocytotoxic activity in sera from patients with ulcerative colitis and Crohn's disease and their household contacts (Korsmeyer et al., 1974; 1975). Since cold lymphocytotoxins occur in viral disease (Mottironi and Terasaki, 1970), these authors have suggested that this finding may indicate an exposure to a common environmental agent. Despite circumstantial evidence for a viral aetiology, there have been relatively few electron microscopic studies in Crohn's disease (Aluwihare, 1971; O’Connor, 1972; Cook and Turnbull, 1975) and, to our knowledge, until now no attempt has been made to visualise viral particles directly by immune electron microscopy.

\footnotetext{
${ }^{1}$ Address for reprint requests: Professor Ralph Wright, Professorial Medical Unit, South Laboratory and Pathology Block, Southampton General Hospital, Southampton, SO9 4XY.
}

Received for publication 10 June 1976

\section{Methods}

TISSUE SPECIMENS

Twelve resected specimens of histologically confirmed Crohn's disease were examined, 10 from the ileum and two from the colon. One small intestinal lymphoma was also studied. Four control specimens of apparently normal intestine from patients having resections for a strangulated hernia, a small intestinal diverticulum and two for a carcinoma of the colon were examined. All specimens were taken at operation, washed in normal saline to remove luminal debris, snap frozen at $-70^{\circ} \mathrm{C}$, and subsequently stored at $-20^{\circ} \mathrm{C}$. All subsequent manipulations, including centrifugation, were conducted at $4^{\circ} \mathrm{C}$. Sixty grams of tissue were homogenised for four minutes in an MSE homogeniser in $60 \mathrm{ml}$ glycine/ hydrochloric acid buffer at $\mathrm{pH} 2.9$. This $\mathrm{pH}$ was selected to prevent complexing of any viral particles with antibody that might be present in the specimen. The homogenate was spun at $2800 \mathrm{~g}$ in an MSE 6L centrifuge for 30 minutes to remove particulate matter. The resultant supernatant was spun at $10000 \mathrm{~g}$ for 30 minutes in an MSE superspeed 75, six of the 12 specimens having been previously concentrated 25-fold by the use of a minicon (Amicon Mass. U.S.A.). The second supernatant was spun at $140000 \mathrm{~g}$ for two hours, using a swing-out rotor in an MSE superspeed 75. The pellet so obtained was resuspended in glycine/ $\mathrm{HCl}$ buffer at $\mathrm{pH} 2.9$ to give a concentrate from which aliquots were taken for (1) direct electron microscopy with negative staining (Almeida and Waterson, 1969); (2) dialysis followed by immune electron microscopy (Almeida and Waterson, 1969); (3) density gradient centrifugation, and (4) storage at $4^{\circ} \mathrm{C}$. 


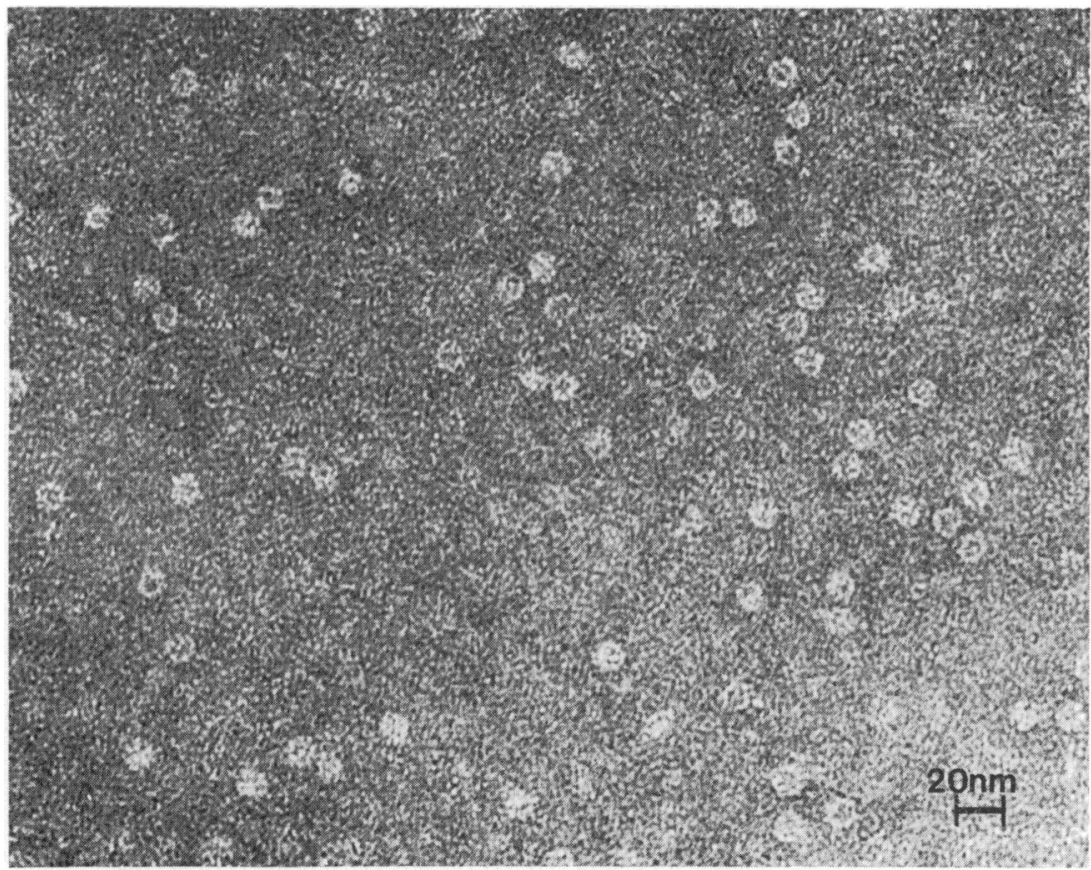

Fig. 1 Particles (12 nm) from a resected specimen of Crohn's disease tissue. $\times 250000$

Direct electron microscopy A drop of the concentrate was placed on a formvar carbon-coated grid, partially dried, washed three times in distilled water and finally stained with $3 \%$ potassium phosphotungstate at $\mathrm{pH} 6.5$. The grids were then examined, using a Philips 201 electron microscope.

Immune electron microscopy A sample of the concentrate was dialysed against phosphate-buffered saline $\mathrm{pH} 7.4$ for 24 hours to raise the $\mathrm{pH}$ and facilitate immune complexing. In the absence of a known antibody to the postulated infectious agent, varying quantities of pooled Crohn's sera were added to equal volumes of the concentrate on the assumption that the serum pool might contain specific antibodies. After standing overnight, a drop of the mixture was placed on a grid and stained and examined as described above.

Density gradient centrifugation One millilitre of the concentrate was placed on a solution of $4 \mathrm{ml}$ caesium chloride $(0.625 \mathrm{~g} / \mathrm{ml})$ made up in glycine/ $\mathrm{HCl}$ buffer $\mathrm{pH} 2.9$, which gave a density gradient between 1.28 and 1.60 after 24 hours centrifugation at $140000 \mathrm{~g}$ using a swing-out rotor in an MSE superspeed 75 . The gradient was collected in $0.25 \mathrm{ml}$ fractions, the density of each fraction was estimated by measuring the refractive index and then reading the density from a calibration curve. A drop from each fraction was taken for direct electron microscopy and the rest dialysed and treated for immune electron microscopy as described above.

\section{STOOL SPECIMENS}

Stool specimens were obtained from nine patients with Crohn's disease and two normal controls and stored at $-20^{\circ} \mathrm{C}$. Using a method similar to that described by Flewett et al. (1974), faeces were suspended $10 \%$ weight by volume in phosphatebuffered saline $\mathrm{pH} \mathrm{7 \cdot 4}$. The suspension was homogenised for three minutes in an MSE homogeniser and then centrifuged at $2800 \mathrm{~g}$ in an MSE 6L centrifuge. The supernatant was then spun at $10000 \mathrm{~g}$ in an MSE superspeed 75 and the resultant supernatant concentrated 25 -fold in a minicon. Faecal concentrate $(0.5 \mathrm{ml})$ was mixed with $0.2 \mathrm{ml}$ of Crohn's or normal serum, allowed to stand overnight, and then centrifuged at $140000 \mathrm{~g}$ for two hours. The pellet was resuspended in phosphatebuffered saline and placed on a grid as before. The technique was verified using a known positive stool containing rotavirus(Dr T.H. Flewett, Birmingham).

\section{Results}

\section{TISSUE SPECIMENS}

No consistent viral particles common to the Crohn's disease tissue were observed by either direct or 
immune electron microscopy of any of the fractions or concentrates. A small $12 \mathrm{~nm}$ particle of density 1.45 was found in abundance in all the Crohn's specimens examined (Fig. 1) and in the small intestinal lymphoma. By contrast, after lengthy scanning only very occasional particles which appeared to be morphologically similar to those illustrated were seen in two of the controls but not in the remainder. The particles were not clumped by Crohn's or normal sera.

\section{STOOL SPECIMENS}

Phages and bacterial flagellae were a common finding and in one case probable enteroviruses were seen. But again no consistent viral or phage particle common to Crohn's disease was visualised, nor did there appear to be any specific clumping by sera.

\section{Discussion}

In the present study, we have been unable to demonstrate viral particles peculiar to Crohn's disease in intestinal tissue or stools, although the methods used have been successful in identifying core particles of hepatitis B from liver homogenates (Almeida et al., 1970) and viruses from stool specimens (Flewett et al., 1974). Despite our inability to isolate a virus in Crohn's disease, it should be emphasised that this does not exclude the possibility of a virus being present, particularly if it is small and in low concentration. It would seem from the data at present available that, if a virus were of importance in the pathogenesis of Crohn's disease, then it could be a common agent to which some individuals have an abnormal response. By analogy with HBsAg positive liver disease, tissue damage in Crohn's disease may be variable, only certain cells being affected, and homogenisation of whole tissue would much dilute the virus, making recognition difficult even if followed by a concentration process. To visualise viral particles from a suspension, they need to be present at a concentration of $10^{6} / \mathrm{ml}$ before one obtains a distribution of one virus per grid square, assuming a 200-mesh grid (Flewett and Boxall, 1976). Consequently, small viruses in low concentration can easily escape detection. By immune electron microscopy, viral particles are agglutinated by a process of complexing, thus making recognition easier and enhancing detection. The problem when applied to Crohn's disease is that it is not known whether specific antibody is present in the serum and at what concentration. To try to overcome this problem, we used various combinations of sera from acute untreated cases, chronic cases, and those who were in apparent remission, but with negative results.

The $12 \mathrm{~nm}$ particle isolated is too small for any known virus. Almeida (personal communication)

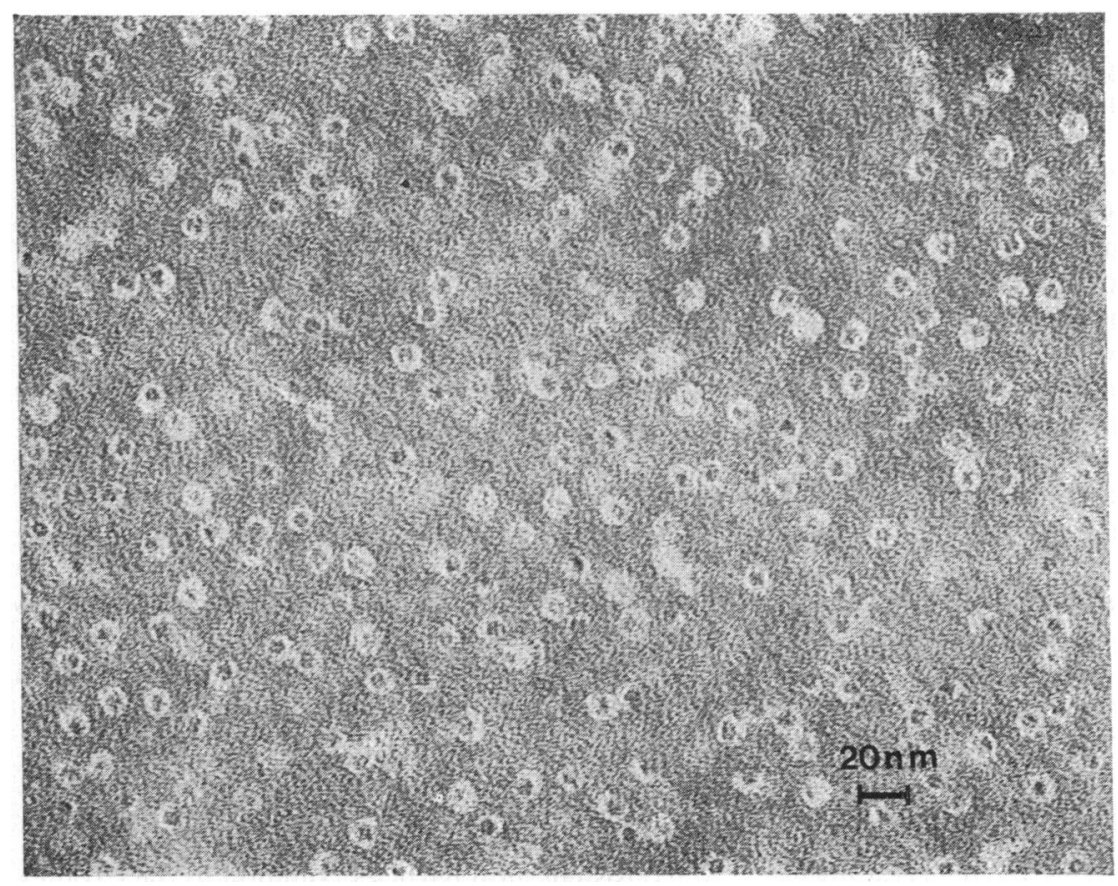

Fig. 2 Particles (12 nm) of horse spleen ferritin. $\times 250000$. 
suggested that these particles resemble ferritin, and we have confirmed this in two ways. Firstly, negative staining and electron microscopy of purified horse spleen ferritin revealed particles of identical morphology (Fig. 2). Secondly, radioimmunoassay demonstrated ferritin in those fractions of the gradient containing the particles, the levels showing a close correlation with the particle count. It is of interest that ferritin has been demonstrated in Burkitt's lymphoma and Hodgkin's disease tissue (Eshhar et al., 1974; Order et al., 1974), where it was originally thought to be a tumour-associated antigen (Order et al., 1971; 1972.) Certain diseased cells, such as leukaemic cells (White et al., 1974), have an abnormally high rate of ferritin synthesis, and we think it possible that increased synthesis may also explain our findings of a high ferritin content in Crohn's tissue.

We are grateful to Dr. T. H. Flewett for helpful advice, to Mr. Ray Griffin and Dr. M. Heyworth for assistance with the electron microscopy, to Professor A. Jacobs for ferritin assays, and to Dr. J. M. T. Willoughby and our surgical colleagues for providing specimens of Crohn's tissue.

\section{References}

Almeida, J. D., and Waterson, A. P. (1969). The morphology of virus antibody production. Advances in Virus Research, 15, 307-338.

Almeida, J. D., Waterson, A. P., Trowell, J. M., and Neale, G. (1970). The finding of virus-like particles in two Australia-antigen-positive human livers. Microbios, 6, 145-153.

Aluwihare, A. P. R. (1971). Electron microscopy in Crohn's disease. Gut, 12, 509-518.

Aronson, M. D., Phillips, C. A., and Beeken, W. L. (1974). Isolation of a viral agent from intestinal tissue of patients with Crohn's disease and other intestinal disorders. (Abstract.) Gastroenterology, 66, 661.

Beeken, W. L., Mitchell, D. N., and Cave, D. R. (1976). Evidence for a transmissible agent in Crohn's disease. Clinics in Gastroenterology. Edited by R. Wright. Saunders: Philadelphia (In press.)

Bolton, P. M., Owen, E., Heatley, R. V., Williams, W. J., and Hughes, L. E. (1973). Negative findings in laboratory animals for a transmissible agent in Crohn's disease. Lancet, 2, 1122-1124.

Cave, D. R., Kane, S. P., Mitchell, D. N., and Brooke, B. N. (1973). Further animal evidence of a transmissible agent in Crohn's disease. Lancet, 2, 1120-1122.

Cave, D. R., Mitchell, D. N., and Brooke, B. N. (1975a). Observations on the transmissibility of Crohn's disease and ulcerative colitis. (Abstract.) Gut, 16, 401.

Cave, D. R., Mitchell, D. N., and Brooke, B. N. (1975b). Experimental animal studies of the etiology and pathogenesis of Crohn's disease. Gastroenterology, 69, 618-624.

Cook, M. G., and Turnbull, G. J. (1975). A hypothesis for the pathogenesis of Crohn's disease based on an ultrastructural study. Virchows Archives A. Pathology, Anatomy and Histology, 365, 327-336.

Eshhar, Z., Order, S. E., and Katz, D. H. (1974). Ferritin, a Hodgkin's disease associated antigen. Proceedings of the National Academy of Sciences, 71, 3956-3960.

Flewett, T. H., and Boxall, E. (1976). The hunt for viruses in infections of the alimentary system. An immune electron microscopical approach. Clinics in Gastroenterology. Edited by $\mathbf{R}$. Wright. Saunders: Philadelphia. (In press.)

Flewett, T. H., Bryden, A. S., and Davies, H. J. (1974). Diagnostic electron microscopy of faeces. 1. The viral flora of the faeces as seen by electron microscopy. Journal of Clinical Pathology, 27, 603-614.

Heatley, R. V., Bolton, P. M., Owen, E., Williams, W. J., and Hughes, L. E. (1975). A search for a transmissible agent in Crohn's disease. Gut, 16, 528-532.

Korsmeyer, S., Strickland, R. G., Wilson, I. D., and Williams, R. C., Jr. (1974). Serum lymphocytotoxic and lymphocytophilic antibody activity in inflammatory bowel disease. Gastroenterology, 67, 578-583.

Korsmeyer, S. J., Williams, R. C., Jr, Wilson, I. D., and Strickland, R. G. (1975). Lymphocytotoxic antibody in inflammatory bowel disease: a family study. New England Journal of Medicine, 293, 1117-1120.

Mitchell, D. N., and Ress, R. J. W. (1970). Agent transmissible from Crohn's disease tissue. Lancet, 2, 168-171.

Mottironi, V. D., and Terasaki, P. I. (1970). LymphoCytotoxins in Disease. I. Infectious Mononucleosis, Rubella and Measles, p. 301. Edited by P. I Terasaki. Williams and Wilkins: Baltimore.

O'Connor, J. J. (1972). An electron microscopic study of inflammatory colonic bowel disease. Diseases of Colon and Rectum, 15, 265-277.

Order, S. E., Chism, S. E., and Hellman, S. (1972). Studies of antigens associated with Hodgkin's disease. Blood, 40, 621-633.

Order, S. E., Colgan, J., and Hellman, S. (1974). Distribution of fast- and slow-migrating Hodgkin's tumour-associated antigens. Cancer Research, 34, 1182-1186.

Order, S. E., Porter, M., and Hellman, S. (1971). Hodgkin's disease: Evidence for a tumor-associated antigen. New England Journal of Medicine, 285, 471-474.

Taub, R. N., Sachar, D. B., Siltzbach, L. E., and Janowitz, H. D. (1974a). Transmission of ileitis and sarcoid granulomas to mice. Clinical Research, 22, 559a.

Taub, R. N., and Siltzback, L. E. (1974b). Induction of granulomas in mice by injection of human sarcoid and ileitis homogenates. Proceedings of VI International Conference on Sarcoidosis, pp. 20-21. Edited by K. Iwai, and Y. Hosoda. University of Tokyo Press: Tokyo.

White, G. P., Worwood, M., Parry, D. H., and Jacobs, A. (1974). Ferritin synthesis in normal and leukaemic leukocytes. Nature (London), 250, 584-585. 